\title{
Sublethal effect of concentrations of Metarhizium anisopliae (metsch.) sorok on the larval stage and immunologic characteristics of Diatraea flavipennella (box) (lepidoptera: crambidae)
}

\author{
JENNIFER GUIMARÃES ${ }^{1}$, EDMILSON J. MARQUES ${ }^{1}$, VALÉRIA WANDERLEY-TEIXEIRA ${ }^{2}$, \\ AURISTELA C. DE ALBUQUERQUE ${ }^{3}$, ELIANA M. DOS PASSOS ${ }^{1}$, \\ CÍNTHIA C.M. SILVA ${ }^{1}$ and ÁLVARO A.C. TEIXEIRA ${ }^{2}$ \\ ${ }^{1}$ Departamento de Agronomia - Entomologia, Universidade Federal Rural de Pernambuco, \\ Rua Dom Manuel de Medeiros, s/n, Dois Irmãos, 52171-900 Recife, PE, Brasil \\ ${ }^{2}$ Departamento de Morfologia e Fisiologia Animal, Universidade Federal Rural de Pernambuco, \\ Rua Dom Manoel de Medeiros, s/n, Dois Irmãos, 52171-900 Recife, PE, Brasil \\ ${ }^{3}$ Departamento de Biologia, Universidade Federal Rural de Pernambuco, \\ Rua Dom Manoel de Medeiros, s/n, Dois Irmãos, 52171-900 Recife, PE, Brasil
}

Manuscript received on August 20, 2013; accepted for publication on February 17, 2014

\begin{abstract}
This work aimed to evaluate the effects of Metarhizium anisopliae on Diatraea flavipennella and investigate their immune response. Was observed the effect of M. anisopliae against larvae of D. flavipennella sprayed at concentrations of $10^{3}, 10^{4}, 10^{5}$ conidia / $\mathrm{mL}$, in which showed differences relative the larval period, extending up to 72.0 days in treatment and 25.0 days in the control. The results for hemocytes revealed that the most frequent cells when sprayed at the concentrations of $10^{3}, 10^{5}, 10^{7}$ conidia $/ \mathrm{mL}$ were the prohemocytes, spherulocytes, plasmatocytes and granulocytes in relation to adipohemocytes and oenocytoids. The level of nitric oxide was different between the control and the concentration $10^{7}$ spores / $\mathrm{mL}$ (24), while the activity of phenoloxidase was similar among treatments in 24 and higher concentration $10^{7}$ spores / $\mathrm{mL}(60 \mathrm{~h})$. In biochemical profile of hemocytes was a change in carbohydrates, lipids and proteins in response to the fungus. The results indicate that the fungus $M$. anisopliae can be used in the Integrated Management of $D$. flavipennella by presenting pathogenicity and interfere with their development even when exposed to small concentrations.
\end{abstract}

Key words: Entomopathogen, hemocytes, histochemistry, nitric oxide, phenoloxidases, sugarcane borer.

\section{INTRODUCTION}

The sugarcane (Saccharum spp.) is an important socioeconomic culture in Brazil. Its raw material is used to produce sugar, ethanol, energy cogeneration, animal feed, and organic fertilizers; generating foreign exchange from the export of actions sugar and alcohol (Cesnik and Miocque 2004,

Correspondence to: Valéria Wanderley-Teixeira

E-mail: valeria@dmfa.ufrpe.br
Mapa 2011). However, phytosanitary problems result in significant loss of profits generated by Diatraea genus pests like the moth borer Diatraea flavipennella Fabr. (Lepidoptera: Crambidae) that can cause direct and indirect damages to this culture (Mendonça 1996, Freitas et al. 2007).

A complex set of parasitoids, predators, and entomopathogenic agents occur naturally into the sugarcane ecosystem, acting against many species 
belonging to the Diatraea genus (Mendonça et al. 1996). However, it is hard to control these borers due to the occurrence of their larval phase in the stalk.

Among the entomopathogenic agents, fungi like Metarhizium anisopliae (Metsch.) Sorok. and Beauveria bassiana (Bals.) Vuill. are used as potent biologic control agents against insects. These fungal isolates under concentration of $10^{5}$ conidia $\mathrm{mL}$ reduced the larval viability of Diatraea saccharalis (Lepidoptera: Crambidae) (Oliveira et al. 2008a). 27 isolates of M. anisopliae, pathogen to $D$. saccharalis, were selected by Zappelini et al. (2010). On the other hand, the insects have a complex and efficient defense system against pathogens, in which the first defense line is provided by physical barriers: tegument and digestive tract that initiate immune, cellular, and humoral answers when broken up (Gillespie et al. 1997). The cellular answers occur with the hemocytes participation; the defense success depends on the number and type of cells involved in this mechanism (Russo et al. 2001).

Moth borers of Diatraea genus show variations in the hemocyte dynamics after $M$. anisopliae and $B$. bassiana fungi inoculation (Oliveira et al. 2008b). The insects' humoral defense includes melanization, phenoloxidase, protease, enzymes increasing, as well as potent antimicrobial peptides synthesis (Löwenberger 2001). Many studies still relate the nitric oxide (NO) production with phytotoxic effects against pathogens (Foley and O'Farrell 2003).

Pech and Strand (1996) related that immune functions held by a hemocyte in a specific specie may be performed by a different cell type in another cell. The authors advocate that the study of the function in the defense process can be used for characterizing a cell type since it is correlated with ultra-structural morphology and especially with its components biochemical in cytoplasm.

Thus, this study aimed to analyze the $M$. anisopliae different concentrations effects against D. flavipennella larval phase, the interference on immunologic parameters like hemocyte dynamics, phenol oxidase production, nitric oxide, and total proteins, as well as verify the possible differences in the histochemical profile of hemocytes.

\section{MATERIALS AND METHODS}

CREATION D. FLAVIPENNELLA

The moth borers were grown under laboratory conditions $\left(27 \pm 1{ }^{\circ} \mathrm{C}\right.$, RH $70 \pm 10 \%$ and $12 \mathrm{~h}$ photophase) and were fed with Hansley and Hammond (1968), an artificial diet modified by Araújo et al. (1985). Was used in all bioassays of third instar of moth borers.

EFFECT OF M. ANISOPLIAE FUNGUS ON D. FLAVIPENNELLA

MOTH BORERS

In this study, the fungus $M$. anisopliae, isolate ESALQ 1189, was used. The experiment was carried out in a completely randomized design with four treatments and eight replicates, each one with five moth borers. For this purpose, fungal suspensions at $10^{3}, 10^{4}$, and $10^{5}$ conidia $\mathrm{mL}^{-1}$ concentration were used, while distilled and sterilized water and Tween ${ }^{\circledR} 80$ sticker/spreader at $0.01 \%$ were used for the control (Oliveira et al. 2008a). The moth borers ware sprayed using a micro-atomizer Paasche "VL" brand, with $2 \mathrm{~mL}$ of suspension in each treatment, which were individualized in plastic vessels with a piece of sugarcane stalk and were put in a Biochemical Oxygen Demand (B.O.D.) incubator at $27 \pm 1{ }^{\circ} \mathrm{C}$ and $\mathrm{RH} 70 \pm 10 \%$ and $12 \mathrm{~h}$ photophase. Observations were made daily and the dead moth borers were put in a humid chamber to confirm the death causal agent. Based on confirmed death data, the surviving curves were estimated by Log-Rank test by pair of treatments using the SAS Proc Lifetest (SAS Institute 1999-2001).

TOTAL AND DifFERENTIAL HEMOCYTES COUNTING

Concentrations $10^{3}, 10^{5}$ and $10^{7}$ conidia per $\mathrm{mL}$ of the fungus $M$. anisopliae were used and in the control, sterile distilled water plus Tween ${ }^{\circledR} 80$ adhesive spreader $0.01 \%$. Each treatment used 10 
moth borers at 24, 36, 48, and 60 hour intervals after inoculation. An incision was made with a pair of scissors in the pleural meso-region of the caterpillar and a micropipette collected hemolymph, which was diluted in $20 \mu \mathrm{L}$ of Phosphate Buffered Saline (PBS) solution ( $\mathrm{pH} 7.0$ ). The $10 \mu \mathrm{L}$ of the sample was transferred to a Neubauer chamber and the total number of hemocytes was determined.

For differential counts, $10 \mathrm{~L}$ hemolymph for smear preparation were used and dried for 20 minutes at room temperature, fixed in methanol for five minutes, and stained with Giemsa. Three hundred (300) cells were counted for each individual (10 replicates), according to the Falleiros et al. (2003) and Oliveira et al. (2008b) methods.

Data were submitted to variance analysis in a factorial scheme and submitted to a regression analysis when necessary. The averages were compared by Tukey test at $5 \%$ probability, the plasmocytes data transformed into $\sqrt{ }(\mathrm{x}+0.5)$, and the remaining cells were transformed into arc sen of $\sqrt{ }(\mathrm{x} / 100)$. All analyses were carried out using the SAS statistical program (SAS Institute 1999-2001).

\section{NitRIC OXIDE LEVELS AND PHENOLOXIDASE ACTIVITY}

The hemolymph was collected at $24 \mathrm{~h}$ and $60 \mathrm{~h}$ after the fungal treatment $\left(10^{3}\right.$ and $10^{7}$ conidia $\left.\mathrm{mL}^{-1}\right)$ and control (distilled water). Twenty (20) $\mu \mathrm{L}$ of hemolymph was diluted in $90 \mu \mathrm{L}$ of sulphanilamide $(1 \%)$ in $\mathrm{H}_{3} \mathrm{PO}_{4}(5 \%)$ as a sample. The nitrite $\left(\mathrm{NO}_{2}{ }^{-}\right)$ content in the samples was correlated with absorbance values obtained from the standard curve of sodium nitrite $\left(\mathrm{NaNO}_{2}\right)$ as reference (Green et al. 1981). The data were submitted to the variance analysis and the averages were compared by the Tukey test at $5 \%$ probability, using the SAS statistical program (SAS Institute 1999-2001).

To the phenoloxidase activity, $10 \mu \mathrm{L}$ of hemolymph was diluted in $100 \mu \mathrm{L}$ of PBS (phosphate buffered saline) sample. The measures of phosphate's (PO) absorbance activity in the L-dihydroxyphenylalanine (L-DOPA) substrate in
PBS were read in triplicates during 30 minutes with one-minute interval in Biotek ${ }^{\circledR}$ reader with $490 \mathrm{~nm}$ filter using the Gen5 software.

HISTOCHEMICAL

Different stains were used to mark the hemocyte substances. The carbohydrate was marked with Periodic Acid-Shiff (P.A.S.) and the lipids and mucin were marked with the Sudan Black and Mallory Trichrome stains, respectively (Junqueira and Junqueira 1983).

\section{RESULTS AND DISCUSSION}

EFFECT OF M. ANISOPLIAE ON D. FLAVIPENNELLA MOTH BORERS

Exposing the moth borers to the different $M$. anisopliae concentrations, an extended larval period was verified in addition to causing the death of the moth borers, differing from the control $\left(\chi^{2}=22.56, \mathrm{P}<0.001, \mathrm{df}=3\right)$ indicating that this biological parameter was affected by the pathogenic action. The average survival time of the control moth borers was 22.4 days; all moth borers started the pupal stage on the $25^{\text {th }}$ day. The $10^{3}$ and $10^{4}$ conidia $\mathrm{mL}^{-1}$ treatments presented a sublethal effect, extending the larval period of the moth borers that survived, to an in an average of 45.4 days and 52.1 days, respectively. The highest concentration was for $10^{5}$ conidia $\mathrm{mL}^{-1}$ with the average survival time reduced to 28.1 days, showing a direct effect on the mortality of moth borers (Figure 1).

M. anisopliae fungus, isolate E9, affected $D$. saccharalis larval viability in $34.2 \%$ at $10^{5}$ conidia $\mathrm{mL}^{-1}$; and more than $50 \%$ of the remaining larvae reached the pupal phase (Oliveira et al. 2008a). According to the results found in this study and also knowing that there are variations among different isolates of the same species, it is possible to conclude that $D$. flavipennella may be more susceptible to $M$. anisopliae than D. saccharalis. However, the tested isolate proved to be efficient for controlling the studied pest, because it promoted larval period elongation, besides not having favored the insects reach the pupal stage. Such elongation may have occurred as an escape mechanism due to adverse 


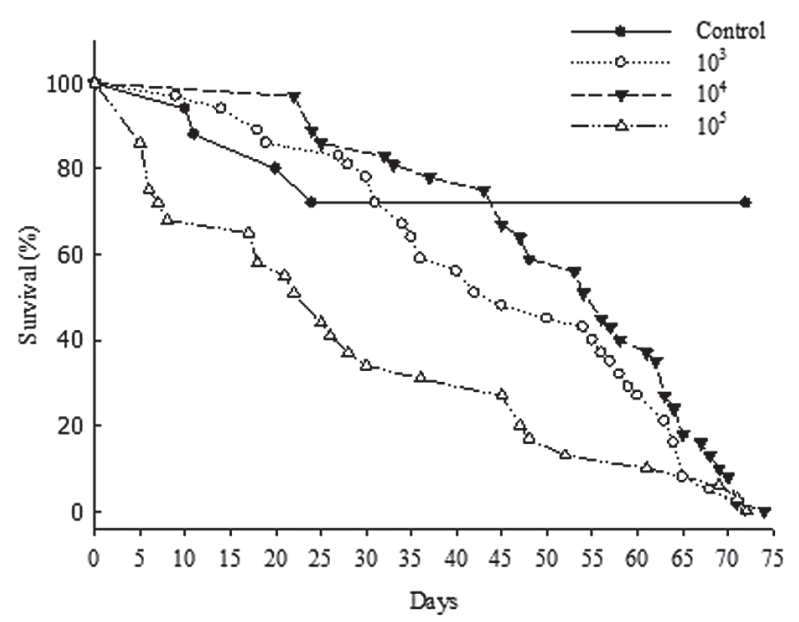

Figure 1 - Age-specific mortality of Diatraea flavipennella larvae treated with different concentrations of Metarhizium anisopliae. Note: survival curves estimated through KaplanMeier method and pairwise comparisons of curves by LogRank test $(\mathrm{P}=0.05)$.

condition in attempting to complete its cycle, a fact that occurs in dipterous as verified by Zimmer et al. (2010), who registered an elongation in the pupal phase of Muscinas tabulans (F.) (Diptera: Muscidae) after treatment with fungal suspensions of $M$. anisopliae $\left(10^{5}\right.$ to $10^{8}$ conidia $\left.\mathrm{mL}^{-1}\right)$.

\section{Total Hemocytes AND DifFERENTIAL COUNTING}

The $10^{3}$ conidia $\mathrm{mL}^{-1}$ treatment showed the higher average of hemocytes $24 \mathrm{~h}$ after spraying, differing only from the $10^{7}$ conidia $\mathrm{mL}^{-1}$ treatment, in which there was a significant reduction of those cells. At the $36 \mathrm{~h}$ evaluation, the $10^{3}$ and $10^{5}$ conidia $\mathrm{mL}^{-1}$ treatments showed the highest averages differing only from the control. At $48 \mathrm{~h}$ after spraying, there were no significant differences between treatments. Finally at $60 \mathrm{~h}$, the $10^{7}$ conidia $\mathrm{mL}^{-1}$ treatment showed the highest average differing only from the $10^{3}$ conidia $\mathrm{mL}^{-1}$ treatment $(\mathrm{F}=0.99, \mathrm{P}=0.4736)$ (Figure 2).

The hemocitarian dynamics in the evaluated treatments remained constant, showing variations only along the evaluation time of the adipohemocytes and spherulocytes, while, for the plasmocytes, prohemocytes, granulocytes, and oenocytoids, the hemocitarian dynamics was variable in the treatments at each

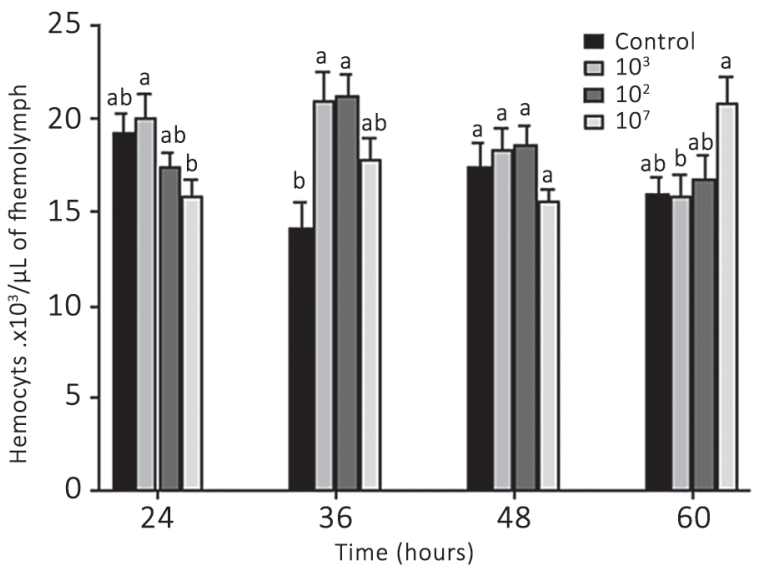

Figure 2 - Hemocytes total counting average (+EP) of third instar of Diatraea flavipennella moth borers sprayed with Metarhizium anisopliae at $10^{3}, 10^{5}$, and $10^{7}$ conidia $\mathrm{mL}^{-1}$ concentrations collected at different times. Bars followed by different letters differ significantly by the Tukey test $(\mathrm{P}<0.05)$.

time. The plasmocytes decreased significantly when compared to control at the higher concentrations at $36 \mathrm{~h}$ $(\mathrm{F}=5.08, \mathrm{P}=0.0049)$, and with $48 \mathrm{~h}(\mathrm{~F}=3.22, \mathrm{P}=0.0343)$ and $60 \mathrm{~h}(\mathrm{~F}=4.27, \mathrm{P}=0.0111)$ at the concentrations of $10^{7}$ and $10^{5}$ conidia $\mathrm{mL}^{-1}$, respectively. The prohemocytes increased significantly when compared to the control at $24 \mathrm{~h}(\mathrm{~F}=3.87, \mathrm{P}=0.0181)$ in the concentration of $10^{5}$ conidia $\mathrm{mL}^{-1}$; and at 60 $\mathrm{h}(\mathrm{F}=4.34, \mathrm{P}=0.0103)$ in the concentration of $10^{7}$ conidia $\mathrm{mL}^{-1}$. The granulocytes showed similar behavior to the control at $24 \mathrm{~h}$. However, at $36 \mathrm{~h}$ $(\mathrm{F}=6.28, \mathrm{P}=0.0015)$ and $60 \mathrm{~h}(\mathrm{~F}=4.91, \mathrm{P}=0.0060)$, they increased considerably to $10^{5}$ conidia $\mathrm{mL}^{-1}$ concentration, while at $48 \mathrm{~h}$ there was a reduction in the two higher concentrations $(\mathrm{F}=5.11, \mathrm{P}=0.0051)$. To the oenocytoids, there was an increase only at $48 \mathrm{~h}(\mathrm{~F}=4.65, \mathrm{P}=0.0077)$ for the concentration of $10^{3}$ conidia $\mathrm{mL}^{-1}$, differing from the control in the concentration of $10^{5}$ conidia $\mathrm{mL}^{-1}$ (Figure 3 ).

The immediate reduction ( $24 \mathrm{~h}$ ) of hemocytes at $10^{7}$ conidia $\mathrm{mL}^{-1}$ concentration can be related to the higher substance released by fungus; Griesch and Vilcinskas (1998), studying the action of M. anisopliae on Galleria mellonella (L.) (Lepidoptera: Pyralidae) hemocytes, concluded that 


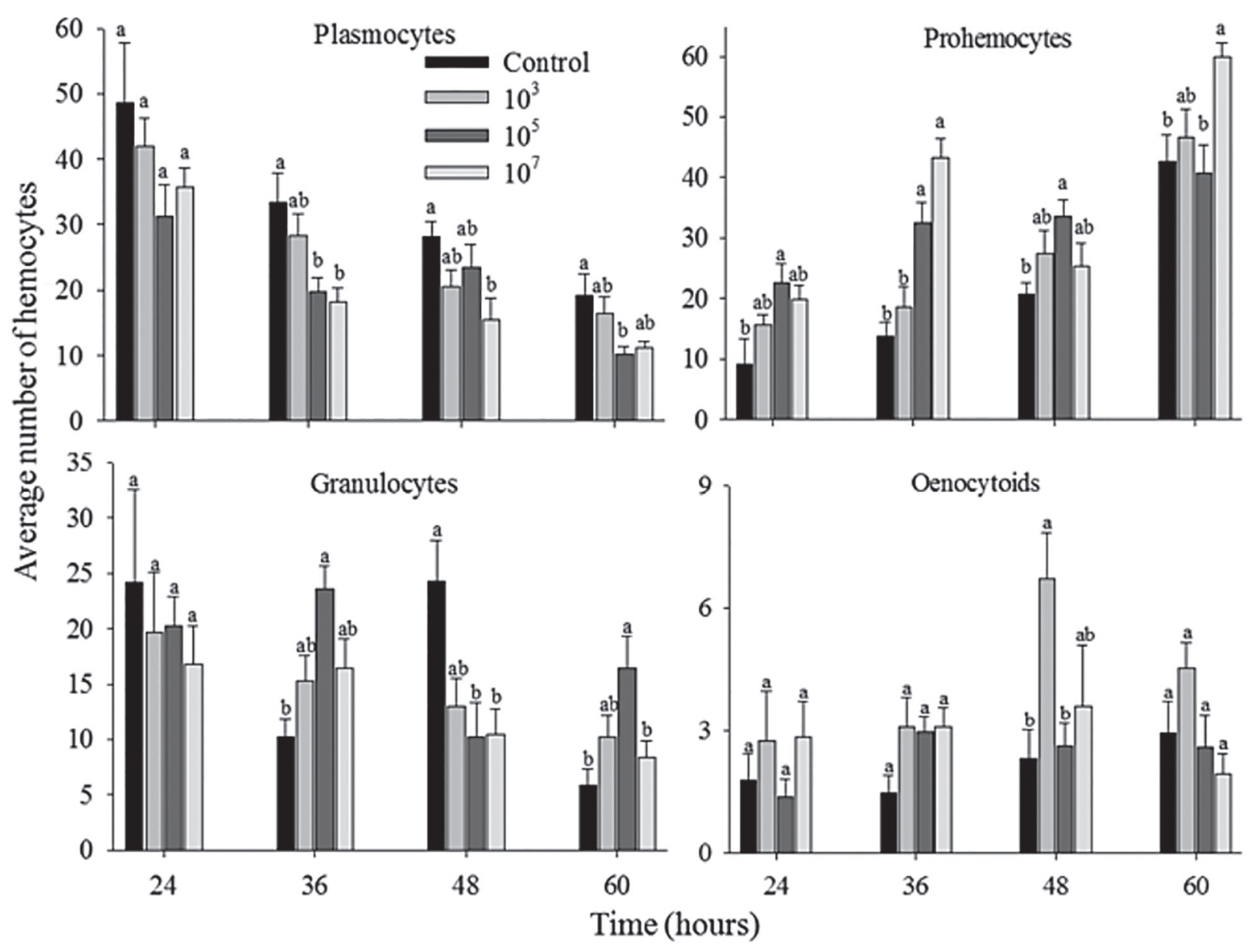

Figure 3 - Diatraea flavipennella moth borers hemocytes differential counting average (+EP) sprayed with Metarhizium anisopliae at $10^{3}, 10^{5}$, and $10^{7}$ conidia $\mathrm{mL}^{-1}$ at intervals of $24,36,48$, and 60 hours after the treatment. Averages with different letters along the time differ between the two treatments by the Tukey test $(\mathrm{P}<0.05)$.

fungus can produce extracellular proteases, which seem to participate in the suppression of cellular immunological response. The significant increase in the hemocytes number in the $10^{7}$ conidia $\mathrm{mL}^{-1}$ concentration at $60 \mathrm{~h}$ may be related to the increase of prohemocytes amount, which had its production increased to undergo differentiation in one or more types of hemocytes to act in the defense. Variation in the hemocytes amount of caused by entomopathogenic fungi was also observed by Balavenkatasubbaiah and Nataraju (2005), suggesting that this fact is due to the progress of infection. The prohemocytes are considered stem cells, therefore, they do not participate directly in the defense processes (Andrade et al. 2004); however, the behavior here reported shows that along the infection in higher concentration there is an increase in this type of cell. Such situation suggests direct or indirect participation in differentiating into other types of hemocytes in the defense mechanism since the same cell type can exhibit different functions and the same function can be developed by different types of cells (Ribeiro and Brehélin 2006).

The hemocytes variation arises from two factors: (a) specific hemocytes production to fight invading organisms; (b) hemocytes immobilization in nodules and capsules around the invading cells and tissues. While the first factor tends to increase the hemocytes 
amount as the granulocytes responsible by the action against invaders, the second factor tends to reduce the number of hemocytes as plasmocytes involved to the encapsulation process (Alves and Pereira 1998). This information confirms the results obtained from this study for the plasmocytes and granulocytes, considering that the plasmocytes were reduced in the higher concentrations, from $24 \mathrm{~h}$, while the granulocytes were increased at $36 \mathrm{~h}$ and $60 \mathrm{~h}$. Negreiro et al. (2004) stated that the role of granulocytes and plasmocytes is related mainly to the phagocytosis and the nodule and capsule formation. In this case, it can be related to the behavior observed in this study when the fungus structures reach the insect's hemocele.

The spherulocytes variation can be related to the mechanic damages caused by the hyphae growth and toxin production (Inglis et al. 2001) because these cells are involved in the cuticular compounds transport, according to Sass et al. (1994). The adipohemocytes reduction may have occurred because they do not have a specific function in the cellular defense and by consequence are more vulnerable to pathogens (Lavine and Strand 2002). Now, the oenocytoids have phenoloxidase precursors, which probably play a role in the melanization (Jiang et al. 1997).

NitRIC OXIDE LeVELs AND PheNOLOXIDASE ACTIVITY ON HEMOLYMPH

The average production of nitric oxide on $D$. flavipennella moth borers showed differences between the control and the $10^{7}$ conidia $\mathrm{mL}^{-1}$ treatment $(\mathrm{F}=5.29, \mathrm{P}=0.0115)$ evaluated at $24 \mathrm{~h}$ after application of $M$. anisopliae spray. However, there was no difference between these two treatments at 60 $\mathrm{h}$ of spraying $(\mathrm{P}>0.05)$ (Figure 4$)$. The nitric oxide levels suggest that this kind of reaction usually occurs just after the foreign body perception, confirming other studies that show the increase of nitric oxide production in insect hemolymph as a response to the foreign bodies (Faraldo et al. 2005, Molina-Cruz et al. 2007).

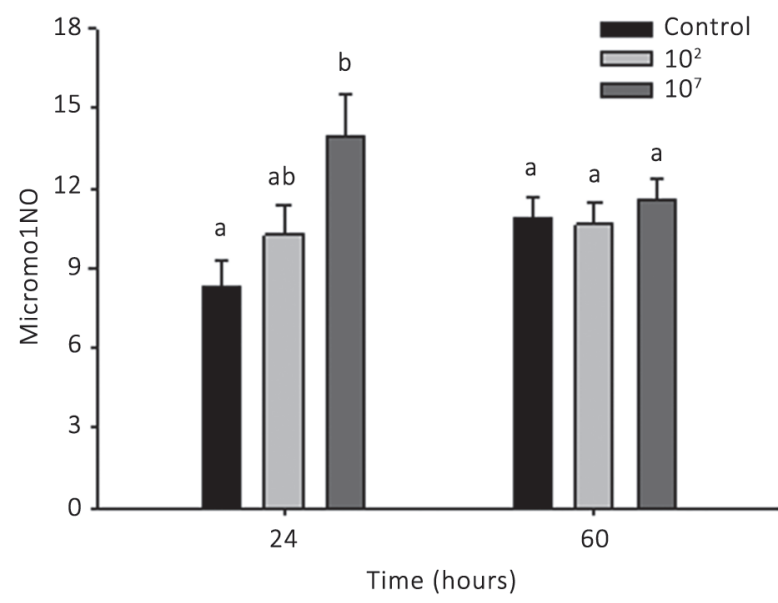

Figure 4 - Nitric oxide concentrations ( $\mu \mathrm{M}$ of $\mathrm{NO}_{2}^{-} / \mu \mathrm{L}$ hemolymph) in Diatraea flavipennella moth borers submitted and no-submitted to Metarhizium anisopliae under different concentrations, evaluated at two different times. Bars followed by different letters differ significantly by the Tukey test $(\mathrm{P}<0.05)$.

No difference was observed in phenoloxidase activity in the hemolymph of $D$. flavipennella larvae untreated and treated with yeast suspensions at the concentrations tested at intervals of $24 \mathrm{~h}$ and $36 \mathrm{~h}$ ( $\mathrm{F}=1.47, \mathrm{P}=0.2477$ ). Already within 60 hours, in the treatment $10^{7}$ conidia $/ \mathrm{mL}$, the phenoloxidase remained at constant levels in relation to previous period, while in the treatment $10^{3}$ conidia / $\mathrm{mL}$ and the control had lower activity $(\mathrm{F}=3.02, \mathrm{P}=0.0126)$ (Figure 5). The control and $10^{3}$ conidia $\mathrm{mL}^{-1}$ treatments behavior for the phenoloxidase may be related to the caterpillar ecdysis, in which there are melanization and consequent prophenoloxidase activation. The longer the fungus contact, as well as infection higher level, smaller is the enzyme activity when compared to the first time interval. The $10^{7}$ conidia $\mathrm{mL}^{-1}$ treatment has immediate response to infection, remaining this way throughout at $60 \mathrm{~h}$. This occurs because the phenoloxidase catalyzes the phenolic compounds oxidation present in the insect hemolymph and cuticle having as a result the melanin, which participates in physiological processes like cuticle sclerotization, wound healing, and immunologic defenses (Lee et al. 1999, Silva et al. 2000). 

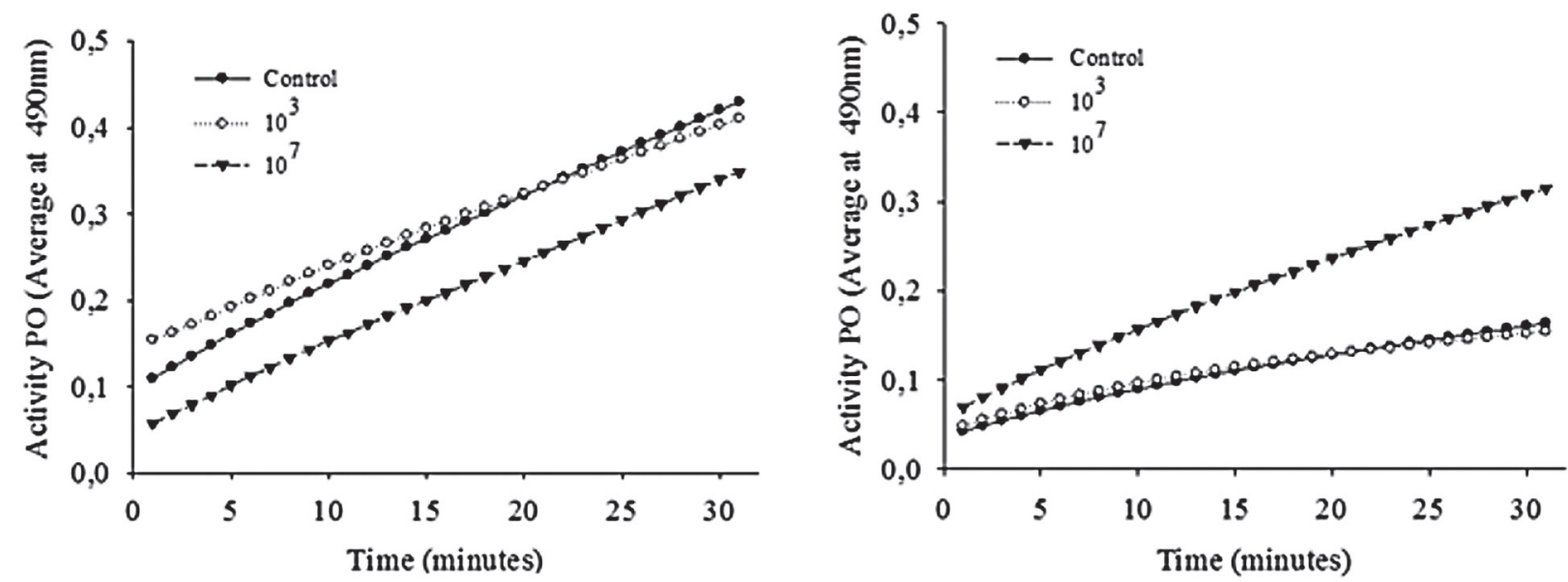

Figure 5 - Phenoloxidase activity, Optical Density (OD) average at 490nm in the Diatraea flavipennella moth borers hemolymph treated with Metarhizium anisopliae, through the time. (A) Evaluated at $24 \mathrm{~h}$ after spraying. (B) Evaluated at $60 \mathrm{~h}$ after spraying ( $\mathrm{n}=10$ moth borers).

Although researches relate pathogenic tolerance to melanization's reactions with consequent involvement of 22 prophenoloxidases cascade (Wilson et al. 2001), very little is known about the phenoloxidase activity in fungi-contaminated insects. Results also showed that numerically there was an oenocytoids reduction in the $60 \mathrm{~h}$ interval at $10^{7}$ conidia $\mathrm{mL}^{-1}$ concentration, thus confirming the participation of these cells in phenoloxidase production in this species.

\section{HISTOCHEMICAL}

Only plasmocytes, granulocytes, prohemocytes, and spherulocytes insect control were reactive to PAS (Figure 6), while the adipohemocytes and oenocytoids did not react to the colorant in any treatment. For the Sudan Black reaction, it was verified that the plasmocytes and adipohemocytes in the control treatment and granulocytes in all treatments were reactive (Figure 7). The prohemocyte was reactive in the control and it showed a mild reaction in the presence of fungus; the spherulocytes and oenocytoids were not reactive. Regarding the Mallory trichomes, the plasmocytes were not reactive to the control, but they were reactive in the presence of fungus. The granulocytes were reactive in all treatments. The prohemocytes showed mild reaction to the control, being reactive in the presence of fungus. Adipohemocytes showed mild reaction in all treatments, while the spherulocytes and oenocytoids did not react (Figure 8).

The histochemical analysis showed that the fungus seem to affect in different ways, the content of carbohydrates, lipids, and mucin in hemocytes, except for oenocytoids. As carbohydrates are highly energetic compounds used in many physiologic processes like in the defense of, tissue repairing, cellular proliferation, being mobilized according to the cell metabolic needs - it is natural that this reducing compound happened in the plasmocytes, granulocytes, prohemocytes, and spherulocytes. The presence of fungus appears to stimulate the release of carbohydrate reserves of these cells, in response to the repair or defense process; also Cunha et al. (2012) observed moth borers growing in Bt cotton in Podisus nigrispinus (Dallas) (Heteroptera: Pentatomidae) and digestive cells fed with Spodoptera frugiperda (J.E. Smith) (Lepidoptera: Noctuidae).

The plasmocytes, adipohemocytes, and prohemocytes suffered reduction in the lipids content, indicating that this cells metabolic rate in presence of fungus did not allow the accumulation of this. However, the fungus seem to stimulate the mucines of production in the plasmocytes and prohemocytes. According to Nieuw Amerogen and 


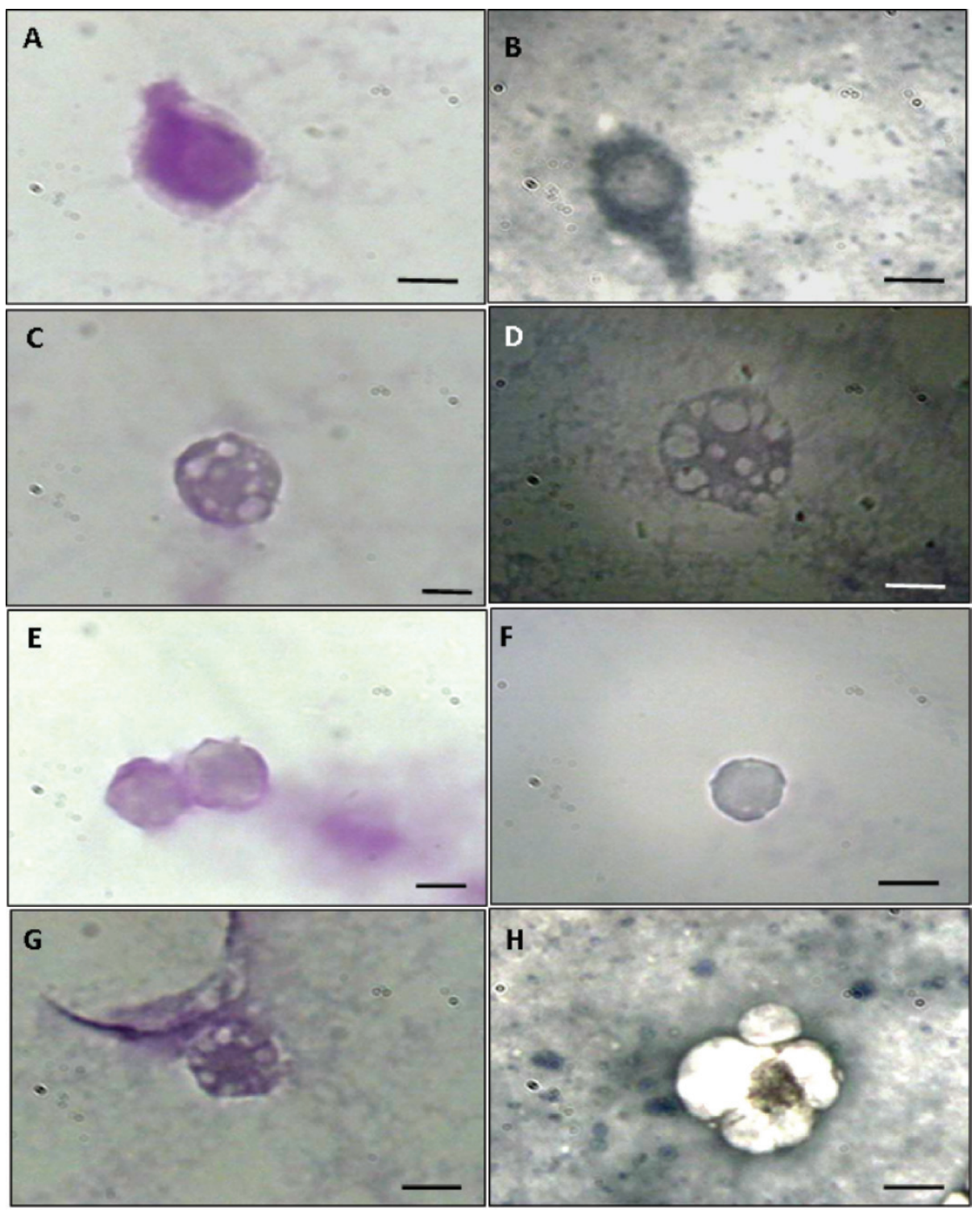

Figure 6 - Plasmocytes (A: control; B: $10^{3}$ conidia $\mathrm{mL}^{-1}$ treatment at $24 \mathrm{~h}$ ); Granulocytes (C: control; D: $10^{3}$ conidia $\mathrm{mL}^{-1}$ treatment at $24 \mathrm{~h}$ ); Prohemocytes (E: control; F: $10^{3}$ conidia $\mathrm{mL}^{-1}$ treatment at $24 \mathrm{~h}$ ) and Spherulocytes (G: control; $\mathrm{H}: 10^{3}$ conidia $\mathrm{mL}^{-1}$ treatment at $24 \mathrm{~h}$ ) of Diatraea flavipennella third instar larvae sprayed with Metarhizium anisopliae and colored with Periodic Acid of Schiff (P.A.S.). Bars $=25 \mu \mathrm{m}$.

Veerman (2002), the mucines are glycoproteins with microbiological function that act in the invading aggregation and encapsulation in vertebrates; it seems that the insects have the same function justifying their higher production in the presence fungus, regardless the concentration or evaluation time. The negative reaction observed in oenocytoids may occur because these cells store large amounts of proteins (prophenoloxidase) and little carbohydrates and lipids, contributing more effectively to the humoral response (Lavine and Strand 2002).

In conclusion, the use of $M$. anisopliae in low concentrations can be an alternative for the control of D. Alavipennella interfering in its life cycle, 


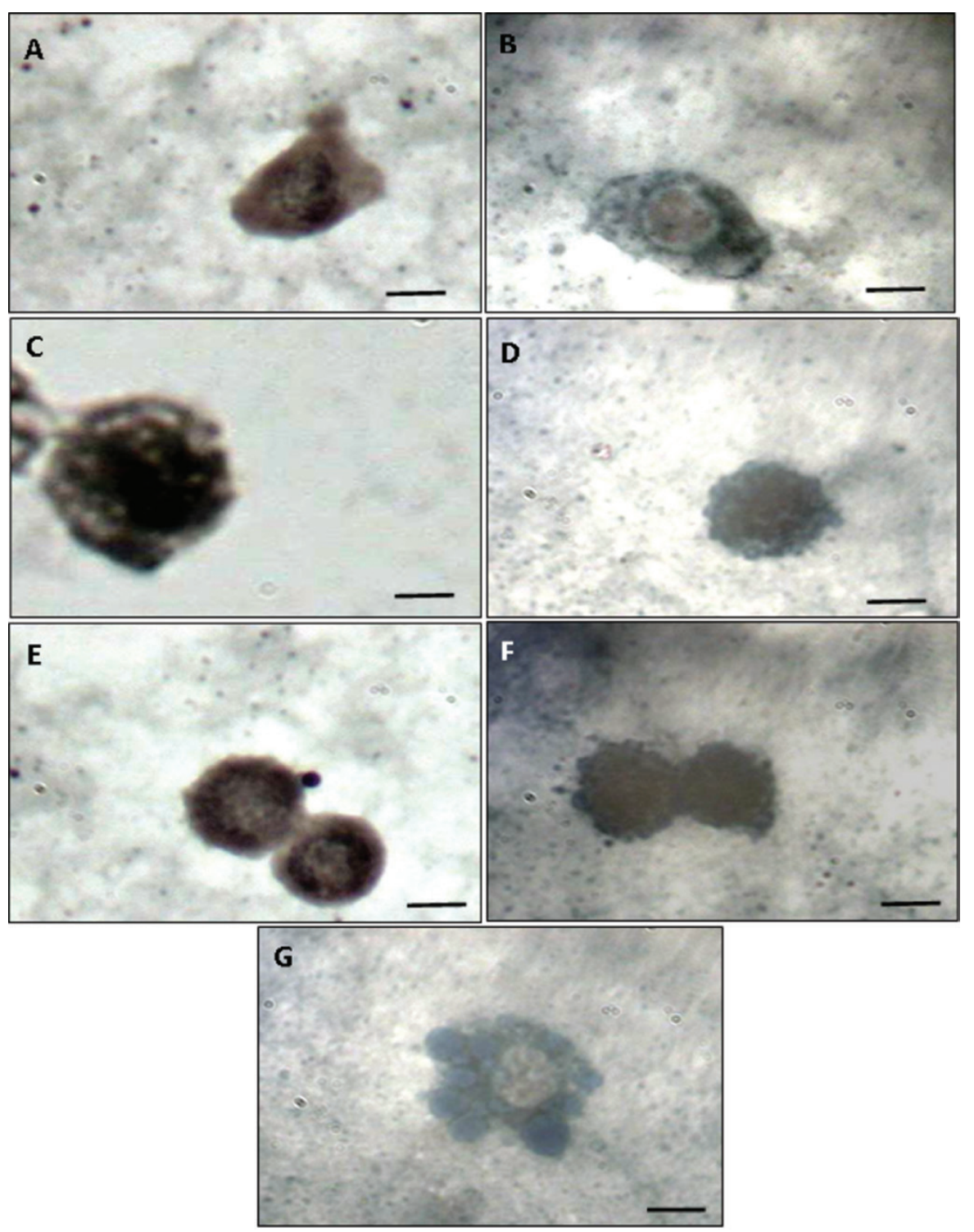

Figure 7 - Plasmocytes (A: control; B: $10^{3}$ conidia $\mathrm{mL}^{-1}$ treatment at $24 \mathrm{~h}$ ), Granulocytes (C: control; D: $10^{3}$ conidia $\mathrm{mL}^{-1}$ treatment at $24 \mathrm{~h}$ ), Prohemocytes (E: control; F: $10^{3}$ conidia $\mathrm{mL}^{-1}$ treatment at $24 \mathrm{~h}$ ) and Adipohemocytes (G: control) of Diatraea flavipennella third instar larvae sprayed with Metarhizium anisopliae and colored with Sudan Black. Bars $=25 \mu \mathrm{m}$.

cellular and humoral immunity, and the biochemical content of the hemocytes is a preponderant factor in overcoming the insect's defenses.

\section{RESUMO}

Este trabalho teve como objetivo avaliar os efeitos de Metarhizium anisopliae, sobre Diatraea flavipennella e investigar sua resposta imune. Foi observado o efeito de
M. anisopliae sobre lagartas de D. flavipennella, pulverizado nas concentrações de $10^{3}, 10^{4}, 10^{5}$ conídios $/ \mathrm{mL}$, no qual apresentou diferenças com relação ao período larval, prolongando até 72,0 dias nos tratamentos e 25,0 dias na testemunha. Os resultados referentes aos hemócitos revelaram que as células mais frequentes quando pulverizado nas concentrações de $10^{3}, 10^{5}, 10^{7}$ conídios/mL foram prohemócitos, esferulócitos, plas- 


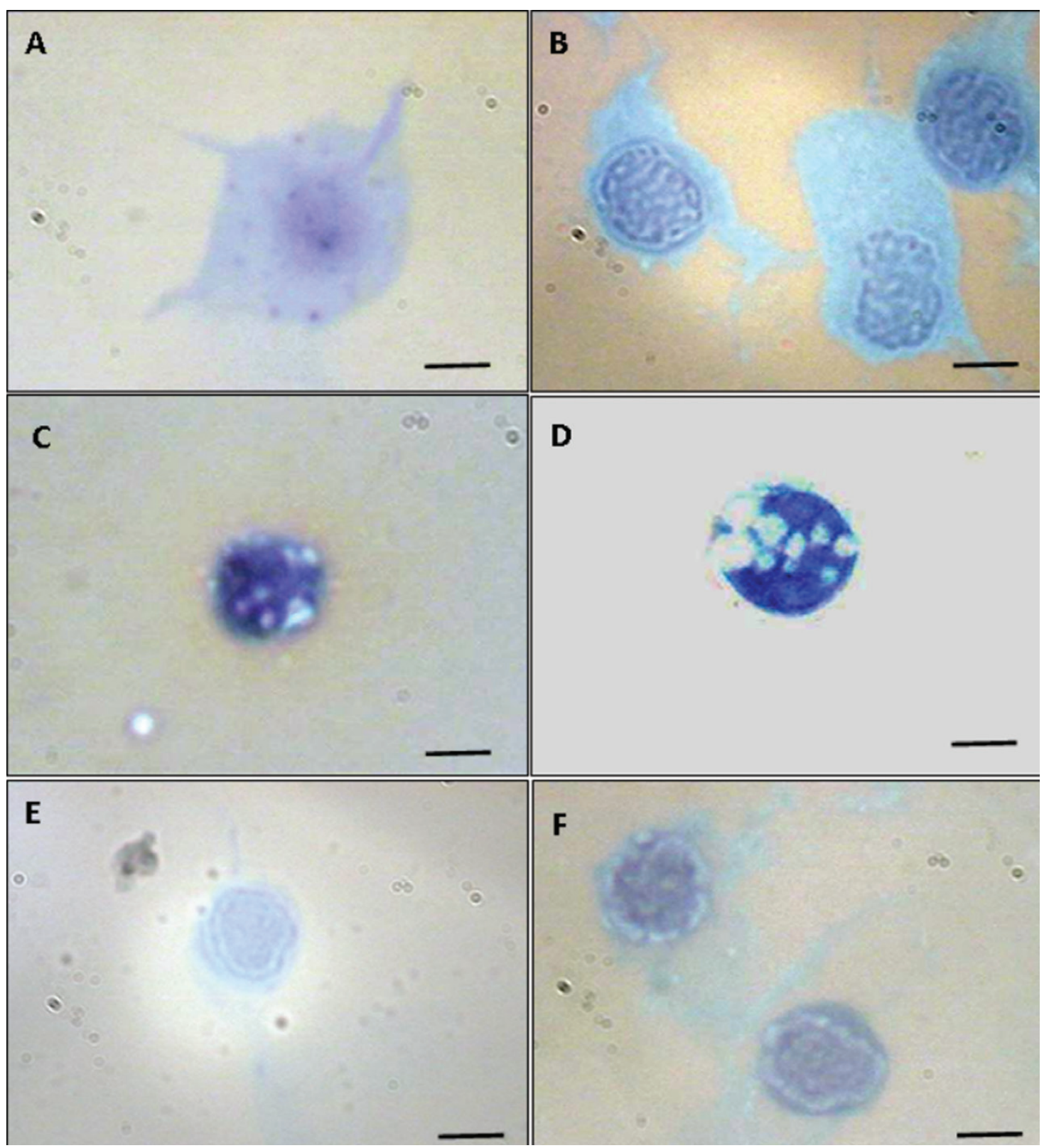

Figure 8 - Plasmocytes (A: control; B: $10^{3}$ conidia $\mathrm{mL}^{-1}$ treatment at $24 \mathrm{~h}$ ), Granulocytes (C: control; D: $10^{3}$ conidia $\mathrm{mL}^{-1}$ treatment at $24 \mathrm{~h}$ ) and Prohemocytes (E: control; F: $10^{3}$ conidia $\mathrm{mL}^{-1}$ treatment at $24 \mathrm{~h}$ ) of Diatraea flavipennella third instar larvae sprayed with Metarhizium anisopliae and colored with Mallory Trichrome. Bars $=25 \mu \mathrm{m}$.

mócitos e granulócitos, em relação aos adipohemócitos e oenocitóides. O nível de oxido nítrico apresentou diferença entre a testemunha e a concentração $10^{7}$ conídios/mL (24h), enquanto a atividade de fenoloxidase foi semelhante entre os tratamentos em $24 \mathrm{~h}$ e superior na concentração $10^{7}$ conídios $/ \mathrm{mL}$ (60h). No perfil bioquímico dos hemócitos, houve uma alteração em carboidratos, lipídios e proteínas em reação ao fungo. Os resultados indicam que o fungo $M$. anisopliae pode ser utilizado no Manejo Integrado de D. flavipennella, por apresentar patogenicidade e interferir no seu desenvolvimento mesmo quando expostas a pequenas concentrações.

Palavras-Chave: entomopatógeno, hemócitos, histoquímica, óxido nítrico, fenoloxidase, Broca da cana-de-açúcar. 


\section{REFERENCES}

Alves SB AND PereIRA RM. 1998. Distúrbios fisiológicos provocados por entomopatógenos. In: Alves $\mathrm{SB}(\mathrm{Ed})$, Controle microbiano de insetos, $2^{a}$ ed., FEALQ, Piracicaba, p. 39-54.

ANDrade FG, Negreiro MCC AND FALleiros AMF. 2004. Aspectos dos mecanismos de defesa da lagarta da soja Anticarsia gemmatalis (Hübner 1818) relacionados ao controle biológico por Baculovirus anticarsia (AGMNPV). Arq Inst Biol 71: 391-398.

ARAÚJO JR, BOTELHO PSM, ARAÚJO SMSS, ALMEIDA LC AND DEGASPARI N. 1985. Nova dieta artificial para criação da Diatraea saccharalis (Fabr.). Rev Tecnol Indúst Açuc Alcool 36: 45-48.

BalaVenKatasubBaiah M ANd NatARAJU B. 2005. Hemocyte changes during the progressive infection of Beauveria bassiana in different breeds of silkworm (Bombyx mori L.). Madras Agric J 92: 431-437.

Cesnik R And Miocque J. 2004. Histórico. In: Cesnik R and Miocque J (Eds), Melhoramento da cana-de-açúcar. Embrapa, Brasília, p. 23-30.

CUnHA FM, CAETANO FH, WANDERlEy-TeIXEIRA V, Torres JB, TeIXEIRA AAC AND Alves LC. 2012. Ultrastructure and histochemistry of digestive cells of Podisus nigrispinus (Hemiptera: Pentatomidae) fed with prey reared on Bt-cotton. Micron 43: 245-250.

FALLEIROS AMF, BOMBONATO MTS AND GREGÓRIO EA. 2003. Ultrastructural and quantitative studies of hemocytes in the sugarcane borer, Diatraea saccharalis (Lepidoptera: Pyralidae). Braz Arch Technol 46: 287-294.

FARALDo AC, SANUNES A, FACCIOLI LH, DEL BEL EA AND LELLO E. 2005. Nitric oxide production in blowfly hemolymph after yeast inoculation. Nitric Oxide 13: 240246.

Freitas MRT, Silva EL, MENDONÇA AL, Silva CE, Fonseca AP, MENDONÇA AL, SANTOS JS, NASCIMENTO RR AND SANT'ANA AEG. 2007. The biology of Diatraea flavipennella (Lepidoptera: Crambidae) reared under laboratory conditions. Fla Entomol 90: 309-313.

FOLEY E AND O FARRELL PH. 2003. Nitric oxide contributes to induction of innate immune responses to gram-negative bacteria in Drosophila. Genes Develop 17: 115-125.

GILLESPIE JP, KANOST MR AND TRENCZEK T. 1997. Biological mediators of insect immunity. Annu Rev Entomol 42: 611-643.

GreEn LC, De LuZURIAGA KR, WAGNER DA, RAND W, ISTFAN N, Young VR AND TANnEnBAum SR. 1981. Nitrate biosynthesis in man. Proc Natl Acad Sci 78: 7764-7768.

GRIESCH J AND VILCINSKAS A. 1998. Proteases released by entomopathogenic fungi impair phagocytic activity, attachment and spreading of plasmatocytes isolated from haemolymph of the greater wax moth, Galleria mellonella. Biocontrol Sci Tech 8(4): 517-531.

INGLIS GD, Goettel MS, Butt TM AND STRASSER H. 2001. Use of Hyphomycetous fungi for managing insects pest. In: BUTTTM ET AL (Eds), Fungi as biocontrol agents progress, problems and potential. Wallingford: CABI Publ, p. 23-70.
Jiang H, WANG Y, Ma C AND KanOST MR. 1997. Subunit composition of pro-phenol oxidase from Manduca sexta: molecular cloning of subunit PPO-pl. Ins Bio Mol Biol 27: 835-850.

JUNQUEIRA LCU AND JUNQUEIRA LMMS. 1983. Técnicas básicas de citologia e histologia, São Paulo: Guanabara Koogan, 123 p.

LAVINE MD AND STRAND MR. 2002. Insect hemocytesand their role in immunity. Ins Bio Mol Biol 32: 1295-1309.

LEE HS, CHO MY, LEE KM, KWON TH AND LEE BL. 1999. The prophenoloxidase of coleopteran insect, Tenebrio molitor larvae was activated during cell clump/cell adhesion of insect cellular defense reactions. FEBS Let 444: 255-259.

LowenBerger C. 2001. Innate immune response of Aedes aegypti. Insect Biochem Mol Biol 31:219-229.

MAPA - Ministério da Agricultura, PeCuÁria E ABASTECIMENTO. 2011. Cana-de-açúcar. Fonte consultada: $<$ http://www.agricultura.gov.br/vegetal/culturas/cana-deacucar> Acesso em 15/12/2011.

MENDONÇA AF. 1996. Guia das principais pragas da cana-deaçúcar. In: Mendonça AF (Ed), Pragas da cana-de-açúcar, Maceió: Insetos \& Cia, p. 3-48.

MendonçA AF, Moreno JA, Risco SH And Rocha ICB. 1996. As brocas da cana-de-açúcar, Diatraea spp. (Lep.,Pyralidae). In: Mendonça AF (Ed), Pragas da canade-açúcar, Maceió: Insetos \& Cia, p. 51-82.

Molina-Cruz A, Dejong RJ, Charles B, Gupta L, Kumar S, JARAMILLO-GUATIERREZ G AND BARILLAS-MURY C. 2007. Reactive oxygen species modulate Anopheles gambie immunity against bacteria and Plasmodium. J Biol Chem 28: 3217-3223.

NEGREIRO MCC, ANDRADE FG AND FALleiros AMF. 2004. Sistema imunológico de defesa em insetos: uma abordagem em lagartas da soja, Anticarsia gemmatalis Hübner (Lepidoptera: Noctuidae), resistentes ao AgMNPV. Semina Cienc Agric 25: 293-308.

Nieuw Amerogen AV AND VeERman ECI. 2002. Salivary glands and saliva. number 2. Saliva the defender of the oral cavity. Oral Dis 8:12-22

OliVEIRA MAP, MARQUES EJ, WANDERLEY-TEIXEIRA V AND BARros R. 2008a. Efeito de Beauveria bassiana (Bals.) Vuill. e Metarhizium anisopliae (Metsch.) Sorok. sobre características biológicas de Diatraea saccharalis F. (Lepidoptera: Crambidae). Acta Sci Biol 30: 220-224.

Oliveira MAP, WANDERLEY-TeIXEIRA V, MARQUes EJ, Albuquerque AC, SANTOS FAB, BArros R AND AAC TEIXEIRA. 2008b. Dinâmica hemocitária em Diatraea saccharalis F. (Lepidoptera: Crambidae) desafiada imunologicamente pelos fungos Beauveria bassiana (Bals.) Vuill. e Metarhizium anisopliae (Metsch.) Sorok. Arq Inst Biol 75: 173-179.

PeCH LL AND STRAND MR. 1996. Granular cells are required for encapsulation of foreign targets by insect haemocytes. J Cell Sci 109: 2053-2060.

RIBEIRO C AND BREHÉLIN M. 2006. Insect hemocytes: What type of cell is that? J Insect Physiol 52: 417-429. 
Russo J, BREhÈLIN M AND CARTON Y. 2001. Hemocyte changes in resistant and susceptible strains of Drosophila melanogaster caused by virulent and a virulent strains of the parasitic wasp Leptopilina boulardi. J Insect Physiol 47: 167-172.

SAS InSTITUTE. 1999-2001. SAS user's guide: Statistics, version $8.2,6^{\text {th }}$ ed. SAS Institute, Cary, NC.

SASS M, KISS A AND LOCKE M. 1994. Integument and hemocyte peptides. J Insect Physiol 40: 407-421.

SILVA C, GARY BD AND RAU ME. 2000. Interaction of hemocytes and prophenoloxidase system of fifth instar nymphs of Acheta domesticus with bacteria. Developm Compar Immunol 24: 367-379.
Wilson K, Cotter SC, ReEsonaf. AND Pell JK. 2001. Melanism and disease resistance in insects. Ecol Let 4: 637-649.

ZAPPELINI LO, ALMEIDA JEM, BATISTA FILHO A AND GIOMETTI FHC. 2010. Seleção de isolados do fungo entomopatogênico Metarhizium anisopliae (Metsch.) Sorok. visando o controle da broca da cana-de-açúcar Diatraea saccharalis (Fabr 1794). Arq Inst Biol 77: 75-82.

ZIMMER CR, CÁRCAMO MC, RIBEIRO PB, AND NASCIMENTO JS. 2010. Ação do fungo Metarhizium anisopliae sobre desenvolvimento do díptero Muscinas tabulans em laboratório. Arq Bras Med Vet Zootec 62: 1142-1147. 